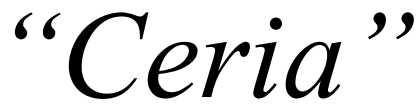

Jurnal Pendidikan Anak Usia Dini

ISSN 2301-9905

Volume 9, No. 2, Januari 2019

Fakultas Keguruan dan Ilmu Pendidikan- Universitas Muhammadiyah Tangerang

\section{Pendidikan Berbasis Kreativitas Pada Mahasiswa PGPAUD Melalui \\ Pemanfaatan Media Barang-Barang Bekas Dalam Pembelajaran Musik \\ Perkusi di Universitas Muhammadiyah Tangerang}

\author{
Eka Yulyawan Kurniawan ${ }^{1}$ \\ ${ }^{1}$ Program Studi Pendidikan Guru Pendidikan Anak Usia Dini \\ Fakultas Keguruan dan Ilmu Pendidikan Universitas Muhammadiyah Tangerang \\ e-mail: 1ekayeka88@gmail.com
}

\begin{abstract}
Abstrak
Pendidikan Guru Pendidikan Anak Usia Dini (PG PAUD) adalah salah satu jurusan di Fakultas Keguruan Ilmu Pendidikan (FKIP) sebagai pencetak calon guru Pendidikan Anak Usia Dini PAUD. seorang Guru PAUD adalah guru pertama siswa didunia pendidikan, pentingnya kompetensi serta kretivitas yang harus dimiliki oleh seorang guru PAUD untuk menghadapi siswa usia dini, maka dari itu pendidikan terhadap mahasiswa PG PAUD harus berbasis kreativitas, karena pada zaman sekarang banyak guru yang hanya terbatas pada buku pembrlajaran saja. Penelitian ini membahas tentang proses pembelajaran seni musik berbasis kreativitas di PGPAUD Universitas Muhammadiyah Tangerang dengan memanfaatkan barang bekas untuk membuat komposisi musik perkusi. Metode penelitian yang digunakan adalah deskriftif kualitatif dengan pendekatan evaluasi, untuk melihat dan mengukur keberhasilan serta hambatan pada saat proses pembelajaran ini berlangsung. Diharapkan mahasiswa PG PAUD nantinya memiliki kreativitas dalam membuat komposisi musik perkusi dengan alat musik dari barang-barang bekas. Dan nantinya mampu mengajarkan musik pada anak usia dini dengan keterbatasan alat musik di PAUD tempat mahasiswa PG PAUD kelak mengajar.
\end{abstract}

Kata kunci: Kreativitas, PAUD, Perkusi 
"Ceria"

Jurnal Program Studi Pendidikan Anak Usia Dini

\section{Pengantar}

Pentingnya Pendidikan dalam kehidupan umat manusia, sebagai arahan untuk menjalani kehidupan yang lebih baik, Hal tersebut membuat Pendidikan formal dimulai sejak Pendidikan Anak Usia Dini (PAUD). Pembelajaran di PAUD merupakan pembelajaran yang sangat penting, karena salah satu syarat untuk masuk Sekolah Dasar saat ini harus siswa lulusan PAUD. siswa yang mengikuti Pendidikan Anak Usia Dini pasti berbeda dengan siswa yang belum pernah mengikuti pelajaran di PAUD, sebelum mendapatkan berbagai macam ilmu pengetahuan, dari mulai belajar berhitung, belajar membaca dan pelajaran lainnya di Sekolah siswa PAUD sudah belajar mengenal pelajaran atau bisa dibilang Pra Sekolah, maka dari itu Guru yang mengajar di PAUD dituntut untuk Kreatif, karena karaktristik siswa PAUD yang dibawah usia 6 tahun lebih sulit dikuasai dibanding usia siswa Sekolah Dasar.

Pendidikan Guru Anak Usia Dini merupakan salah satu jurusan dalam Fakultas Keguruan Ilmu Pendidikan (FKIP). Mahasiswa PGPAUD dituntut untuk mempelajari semua mata kuliah untuk Anak Usia Dini, dari mulai Pisikologi Pendidikan, Agama, Matematika, Bahasa Inggris sampai Matakuliah Seni Rupa, Musik dan Tari. Untuk membentuk siswa yang kreatif maka sebelum menjadi guru, mahasiswa harus dididik menjadi kreatif dan inovatif. Kreativitas dihasilkan dari sebuah pemikiran untuk menghasilkan inovasi baru, kreativitas yang dangkal akan membuat proses pembelajaran akan sulit berkembang karena keterbatasan media, sarana dan prasarana di lingkungan sekolah, untuk itu seorang guru harus kreatif, salah satunya dalam pembelajaran seni musik. Di Sekolah PAUD Seni Musik merupakan salah satu mata pelajaran yang dipelajari siswa, karena seni musik dapat mengembangkan motorik anak dan melalui seni musik anak PAUD bisa belajar hal lain. Namun pada kenyataannya tidak semua sekolah PAUD memiliki fasilitas alat-alat musik, untuk itu guru harus kreatif agar pembelajaran seni musik bisa tetap dilaksanakan dengan keterbatasan yang ada.

Pada kegiatan bermusik, kreativitas memegang kunci utama karena dalam kegiatan bermusikk seseorang ingin menciptakan suatu karya yang inovatif dan belum pernah ada, untuk itu perlu adanya imajinasii, ide dan gagasan dalam membuat karya seni. Pembelajaran perkusi dapat membangun kecerdasan emosional, kegiatan bermusik selain dapat mengembangkan motorik, juga membuat mereka saling menghargai satu sama lain, inivatif, kreatif, dan disiplin. 


\section{"Ceria"}

Jurnal Program Studi Pendidikan Anak Usia Dini

Kegiatan bermusik merupakan bentuk ekspresi yang paling baik. Mahasiswa yang kreatif terlihat dari rasa ingin tahu yang besar, sikap ingin mencoba dan daya imajinasinya. Penelitian yang akan dilakukan ini bertujuan untuk meningkatkan kreativitas Mahasiswa PGPAUD melalui pemanfaatan media berbasis barang-barang bekas dalam pembelajaran perkusi. Mengeksplorasi bunyi dari benda dilingkungan sekitar, dan mengekspresikan rasa musikal mereka melalui bunyi.

Pendidikan berbasis kreativitas merupakan pembelajaran yang menuntut siswa untuk berfikir kreatif dan fleksibel dalam kondisi apapun, berbeda dangan pembelajaran yang berupa hafalan, pembelajaran kreatifitas lebih menekankan kepada praktek. Kreativitas dalam bermusik merupakan kemampuan untuk melakukan suatu tindakan sebagai hasil dari latihan dalam mencipta suatu yang baru dan unik, sehingga bakat dan kreativitas musikal dapat menentukan prestasi belajar anak Suprapti (2006.h.2). Kreativitas dalam belajar musik tidak hanya ditujukan untuk terampil bermain musik saja, tetapi diarahkan untuk memahami proses yang mengarahkan mereka menjadi kreatif. Seperti yang diungkapkan Oskar odena dalam Gunara (2010.h.53), mengemukakan bahwa:

Pada pendidikan musik, kreativitas harus menjadi payung dalam proses pengajaran kreasi seperti mencipta dan improvisasi/eksplorasi bunyi. Kreativitas juga bisa diaplikasikan pada proses pengajaran mendengar karya musik (mendengarkan dengan kreatif), pertunjukan (pertunjukan kreatif) dan semua aktivitas pengajaran musik harus bersandar pada kreativitas.

Pengalaman musikal mahasiswa nantinya yang akan berperan menjai sebuah kreativitas musikal, dari setiap bunyi yang mereka dengar dan dari karakteristik bunyi atau suara dari benda-benda yang ada dilingkungan mereka yang disusun menjadi komposisi musik perkusi sederhana namun original, karena murni hasil dari eksplorasi mahasiswa itu sendiri dalam berkreasi musik.

Pamadhi, (2012.h.195) mengungkapkan bahwa memahami merupakan peristiwa memasukkan estetika melalui penginderaan rasa dan pikir untuk objektifikasi. Sedangkan menjelaskan adalah peristiwa menuangkan gagasan tentang estetika. Dapat pula dikatakan untuk usaha membuahkan kemampuan imajinatif. Sehingga pembelajaran seni dapat berfungsi untuk melatih tingkat pemahaman, menuangkan gagasan, serta melatih daya imajinasi untuk berfikir 
"Ceria"

Jurnal Program Studi Pendidikan Anak Usia Dini

secara kritis.

Dalam pembelajaran perkusi, pengajar harus memiliki bekal ilmu yang mempuni, agar proses pembelajaran perkusi bisa berjalan sesuai dengan apa yang diharapkan. Dalam pembelajaran perkusi, materi seperti ketukan dasar, tempo dan dinamika sangat penting dikuasai oleh pengajar, karena itu materi yang harus didapat oleh siswa.

Instrumen perkusi diklasifikasikan ke dalam bermacam-macam kriteria, kadang-kadang bergantung pada konstruksinya, adat istiadat/tradisi, fungsi dalam teori musik dan orkestra, atau kelaziman dengan pengetahuan umum yang ada. Instrumen perkusi kadang-kadang dikasifikasikan sebagai "instrumen berintonasi" atau "instrumen tak berintonasi". Terdapat beberapa instrumen yang digunakan oleh perkusionis dan komposer dalam permainan musik yang tidak dapat layak dimasukkan sebagai sebuah instrumen musik. Karenanya, untuk membedakan instrumen satu dengan lainnya adalah berdasarkan penerimaan dan pertimbangan dari pendengar secara umum. Contoh, drum, atau kaleng drum yang digunakan untuk menampung minyak sebagai instrumen musik, meski benda-benda tersebut cukup sering digunakan oleh komposer dan perkusionis dalam musik modern yang ada saat ini. Beberapa jenis instrumen musik perkusi yang termasuk dalam kategori ini adalah: Sapu, Pot bunga, Botol galon, Kaleng minuman, Pipa besi, Tas plastik, Kereta belanja, Roda sepeda, Bebatuan, Tong dan lain sebagainya.

Seorang pelatih perkusi harus memiliki bekal ilmu dibidang musik baik secara teori maupun praktek. bekal ilmu teori itu sangat penting karena seorang pengajar musik khususnya perkusi harus bisa memberikan teori seperti, pengenalan bentuk not, mengajarkan tentang harga atau nilai not, not istirahat, birama, dan lainnya. Sama halnya dengan bekal ilmu praktek, karena belajar musik jika tidak dipraktekan merupakan pembodohan. Praktek yang harus diberikan oleh pengajar perkusi misalnya, teknik memegang stick, praktek membaca ritmik, cara memegang instrumen dan lainnya.

Hal yang sangat penting dalam belajar musik yaitu teori dasar musik, karena teori dasar merupakan dasar dalam belajar musik begitu pula dengan Perkusi. Teori dasar musik untuk belajar Perkusi salah satunya : pengenalan bentuk not, nilai atau harga not, membaca ritmik 
"Ceria"

Jurnal Program Studi Pendidikan Anak Usia Dini

sederhana, pengenalan tempo dan lainnya. Menurut Banoe (1989.h.6) jika dipandang dari sudut ritmis, dalam permainan alat musik jenis perkusi merupakan landasan pendidikan tahap awal bagi segala keterampilan bermain alat musik, sedangkan menurut Mahmud Alat musik perkusi atau alat musik pukul merupakan alat musik yang bunyinya ditimbulkan oleh pukulan sebuah benda dengan benda lain Mahmud (1995.h.66). Jadi belajar alat musik perkusi adalah awal untuk belajar alat musik lainnya, karena melalui perkusi rasa musikal bisa terlatih, dan permainan perkusi bisa menggunakan media apa saja yang bukan alat musik, hal ini memudahkan siswa untuk belajar bermusik, karena tidak harus membeli alat musik.

Pembelajaran perkusi yang dilakukan secara berkelompok dapat menggunakan model pembelajaran cooperative learning. Untuk mewujudkan proses pembelajaran yang sesuai dengan prinsip cooperative learning, maka dibutuhkan suatu langkah untuk mewujudkan hasil pembelajaran yang efektif. Adapun langkah-langkah cooperative learning yang dijelaskan oleh Stahl, 1994 dan Slavin, 1983 (dalam Etin solihatin dan Raharjo) sebagai berikut:

“1) Langkah pertama, yang dilakukan oleh guru adalah merancang program pembelajaran; 2) langkah kedua, dalam aplikasi pembelajaran di kelas guru merancang lembar observasi yang akan digunakan untuk mengobservasi kegiatan siswa dalam belajar secara bersama dalam kelompok-kelompok kecil; 3) langkah ketiga, dalam melakukan observasi terhadap kegiataan siswa guru mengarahkan dan membimbing siswa, baik secara individual maupun kelompok, baik dalam memahami materi maupun mengenai sikap dan perilaku siswa selama kegiatan belajar berlangsung; 4) langkah keempat, guru memberikan kesempatan kepada siswa dari masing-masing kelompok untuk mempresentasikan hasil kerjanya".

Dari Ke-empat langkah yang telah dijelaskan di atas, dapat disimpulkan bahwa untuk mewujudkan proses pembelajaran cooperative learning secara maksimal, peran pengajar musik sangat menentukan terutama dalam menetapkan sebuah target. Menyusun langkah-langkah dalam sebuah sistem pembelajaran perkusi. Setelah itu pengjar melakukan pengamatan terhadap hasil kerja dari mahasiswa. Kemudian melakukan pengarahan dan membimbing dengan baik secara individual maupun kelompok. 


\section{Metode}

Metode penelitian yang dipakai dalam penelitian ini yaitu deskriftif kualitatif dengan pendekatan evalusi, deskriftif kualitatif yaitu suatu pendekatan untuk membuat gambaran gambaran mengenai situasi atau kejadian dengan menggunakan data yang dinyatakan secara verbal dan kualifikasinya dan. dengan menganalisis setiap permasalahan yang ada pada saat penelitian yang bersifat teoritis maupun praktek. Menurut Nawawi ( 1995.h.31 ), Penelitian deskriptif merupakan penelitian yang mengungkapkan suatu masalah, keadaan atau peristiwa sebagaimana adanya, sehingga bersifat sekedar untuk mengungkapkan fakta ( Fact Finding ). Sedangkan Penelitian Evaluasi merupakan bagian dari evaluasi dan juga merupakan bagian dari penelitian. Sebagai bagian dari evaluasi, penelitian evaluasi juga berfungsi sebagai evaluasi yaitu proses untuk mengetahui seberapa jauh perencanaan dapat dilaksanakan dan seberapa jauh tujuan program tercapai. Dengan menggunakan penelitian evaluasi, maka data yang diperoleh akan lebih akurat, lengkap, valid, reliable dan obyektif, Sugiyono (2014.h.740)

Penelitian kualitatif lebih mementingkan proses daripada hasil, digunakan untuk meneliti dalam kondisi yang alamiah, dan peneliti merupakan instrument kunci dalam penelitian. Eneliti kualitatif harus bersifat "prespetif emic" artinya memperoleh data "bukan sebagaimana harusnya", bukan berdasarkan apa yang difikirkan peneliti melainkan apa yang sebenarnya terjadi dilapangan, yang dialami, dirasakan, dan difikirkan oleh partisian atau sumber data.

Karakteristik lain yang ada pada penelitian yang menggunakan pendekatan kualitatif seperti posisi peneliti dalam konteks penelitian, unit informasi dan unit analisis, tipe informasi yang dikumpulkan, analisis data serta cara menyimpulkan juga digunakan dalam evaluasi program yang bersifat kualitatif. Format rancangannya mencakup konteks atau pernyataan tentang apa yang mendasari perlunya dilakukan evaluasi terhadap suatu program, kemudian apa tujuan dilakukannya evaluasi program. Selanjutnya akan disepakati dahulu asumsi yang relevan, aturan-aturan dalam pengumpulan informasi serta cara pengumpulan informasi, pengorganisasian data, analisis data, serta verifikasi data (Creswell, John.W, 1994).

Penelitian ini bertujuan untuk mengukur keberhasilan proses pembelajaran perkusi dengan menggunakan barang-barang bekas dalam upaya meningkatkan kreativitas mahasiswa PGPAUD 
"Ceria"

Jurnal Program Studi Pendidikan Anak Usia Dini

di Universitas muhammadiyah Tangerang, Proses penelitian ini mengacu pada 3 tahapan yaitu: Tahap pra-lapangan, tahap kegiatan di lapangan, tahap pasca lapangan.

1. Tahap Pra Lapangan

Peneliti sebagai Dosen Seni Musik di PGPAUD menyusun program pembelajaran perkusi, serta mengukur kreativitas dan pengetahuan mahasiswa terhadap musik perkusi sebelum pembelajaran dilakukan, untuk mengukur tingkatan kreativitas sesudah pembelajaran perkus dilaksanakan.

2. Tahap Penelitian dilapangan

Peneliti melakukan pengamatan dan observasi dalam setiap kegiatan pembelajaran Perkusi di kelas PGPAUD Universitas Muhammadiyah Tangerang dari pertemuan pertama hingga pertemuan terakhir, melakukan pengamatan dari kelompok perkusi maupun individual mahasiswa untuk menilai proses pembelajaran berdasarkan kelompok dan individu. Melakukan evaluasi dan refleksi terhadap proses pembelajaran. Melakukan proses pengumpulan data.

3. Tahap Pasca Lapangan

Setelah kegiatan penelitian selesai dilaksanakan maka peneliti melakukan analisis dan pengolahan data yang telah didapatkan pada saat penelitian berlangsung. Menggunakan data kualitatif yang diperoleh dari hasil catatan pengamatan atau hasil observasi dilapangan dan wawancara, observasi dilakukan selama proses pembelajaran perkusi berlangsung. Analisis telah mulai sejak merumuskan dan menjelaskan masalah, sebelum terjun ke lapangan, dan berlangsung terus sampai penulisan hasil penelitian. Nasution (1988).

Instrument dan Responden Penelitian mencakup

a. Instrument Penelitian

Instrument dalam penelitian kualitatif deskriptif ini adalah peneliti sendiri sebagai human instrument . yaitu berfungsi sebagai yang menetapkan fokus penelitian, memilih informan sebagai sumberdata, menafsirkan data dan membuat kesimpulan dalam temuannya. Dalam pengumpulan data, baik itu wawancara ataupun observasi, 
peneliti juga memerlukan alat bantu seperti pedoman wawancara, pedoman observasi, buku catatan, alat perekam, dan kamera.

b. Responden Penelitian

Responden dalam penelitian ini adalah pihak-pihak yang terlibat dalam kegiatan pembelajaran Perkusi di PGPAUD Universitas Muhammadiyah Tangerang Mahasiswa PGPAUD Semester V Universitas Muhammadiyah Tangerang yang mengikuti kelas matakuliah seni musik AUD.

Teknik pengumpulan data yang digunakan adalah:

1) Observasi

Observasi adalah teknik pengumpulan data yang dilakukan melalui suatu pengamatan, dengan disertai pencatatan-pencatatan terhadap keadaan atau prilaku objek sasaran. Melalui observasi, peneliti akan mengamati jalannya proses kegiatan pembelajaran perkusi,.

2) Wawancara

Kegiatan wawancara merupakan interaksi Tanya-jawab antara peneliti dengan informan atau responden dimana dalam kegiatan tersebut peneliti mencari data yang dia butuhkan untuk penelitiannya. Wawancara bertujuan untuk memperkuat data yang telah ditemukan pada saat observasi bahkan melengkapi data yang belum didapat pada saat observasi.

\section{Hasil dan Pembahasan}

Proses pembelajaran perkusi di PG PAUD Universitas Muhammadiyah Tangerang dilaksanakan setiap hari senin jam 19:00- 20:45 WIB, pembelajaran perkusi dilakukan di ruang kelas H.4.4 gedung A Universitas Muhammadiyah Tangerang. Jumlah mahasiswa PGPAUD yang mengikuti pembelajaran perkusi ada 18 orang. Pada pembelajaran perkusi ini ada tahapan-tahapan sebagai berikut: 

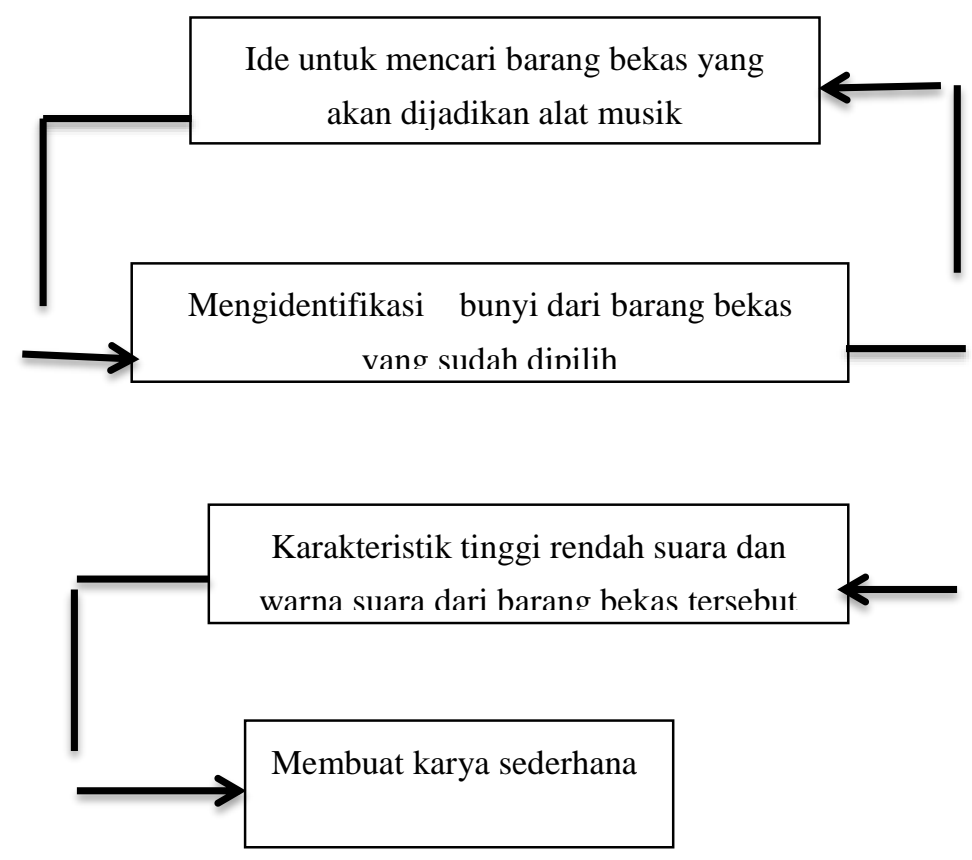

Pada tahap awal proses pembelajaran mahasiswa diajak menonton permainan perkusi dengan barang-barang bekas, sebagai acuan dan motivasi bagi mahasiswa yang akan melaksanakan pembelajaran perkusi, dengan menyaksikan pertunjukan musik perkusi dari barang-barang bekas mahasiswa memiliki ide untuk pemilihan barang bekas apa saja yang akan digunakan pada pembelajaran perkusi, setelah itu pembagian kelompok, pembagian kelompok mahasiswa PGPAUD ada 2, karena jumlah mahasiswa PGPAUD hanya 19 orang maka satu kelompok hanya berjumlah 9 dan 10 mahasiswa.

Pada pertemuan kedua mahasiswa membawa alat musiknya berupa barang-barang bekas, ada yang membawa ember, botol plastik berisi beras atau kacang hijau, botol beling, toples bekas dan lain sebagainya, pada pertemuan kedua ini mahasiswa belajar mengenal karakter suara dari setiap barang bekas yang dibawa, yang tergolong karakter suara tinggi (high), sedang (middle) dan rendah (low). Setelah itu beberapa alat musik tersebut digolongkan berdasarkan karakter suara, dimana alat musik yang bersuara tinggi, sedang 
"Ceria"

Jurnal Program Studi Pendidikan Anak Usia Dini

dan rendah. Mahasiswa belajar berlatuh teknik memukul, dari mulai cara memegang stick, single stroke, double stroke serta paradidle, ini merupakan teknik dasar bermain drum.

Pada pertemuan ketiga mahasiswa sudah mulai mengkonsep karya musik perkusi yang sederhana dari barang bekas yang mereka bawa, pola-pola sederhana yang mereka buat berdasarkan latihan teknik dasar bermain drum, yaitu single stroke, double stroke dan paradidle, selain itu ada beberapa pola yang mereka buat sendiri. Selain berlatih dikampus mahasiswa PGPAUD Universitas Muhammadiyah Tangerang juga berlatih secara berkelompok di rumah. Hal ini membuktikan bahwa mereka sangat antusias untuk membuat komposisi musik perkusi,

\section{Kesimpulan}

Proses pembelajaran Perkusi dengan media barang bekas pada mahasiswa PGPAUD Universitas Muhammadiyah Tangerang berjalan dengan lancar, adapun hambatan pada proses pembelajaran adalah waktunya yang terbatas, akan tetapi mahasiswa memiliki semangat untuk berlatih dirumah. Kreativitas dari mahasiswa berbeda-beda, dari mulai pemilihan barang bekas yang cocok untuk dijadikan alat musik perkusi, cara membunyikannya dan membuat pola-pola sederhana untuk garapan musik perkusi.

Kegiatan pembelajaran perkusi ini selain menggali kreativitas mahasiswa dan kerjasama dalam kelompok musik, sikap disiplin mahasiswa-pun bisa dilihat didalam proses pembelajaran perkusi, meskipun dengan keterbatasan waktu latihan dikelas mereka tetap berlatih dirumah. Untuk latihan perkusi memang harus dilakukan ditempat yang khusus dimana mahasiswa bisa fokus latuhan tanpa adanya kekhawatiran mengganggu kelas lain, karena karakter bunyu yang dihasilkan dengan cara dipukul lebih keras dibanding alat musik lainnya.

Diharapkan adanya ruang khusus untuk proses pembelajaran seni musik, yang kedap suara dan memiliki ruangan yang cukup luas, agar proses pembelajaran musik perkusi bisa berjalan lebih 
"Ceria"

Jurnal Program Studi Pendidikan Anak Usia Dini

baik lagi, dan diharapkan bagi Mahasiswa PGPAUD yang mengikuti pembelajaran perkusi dengan menggunakan barang-barang bekas bisa menjadi calon guru PAUD yang kreatif nantinya, bisa mengajar musik dengan kreatif meskipun dengan keterbatasan alat musik. Karena dalam kreativitas tidak pernah ada keterbatasan.

\section{Daftar Acuan}

Banoe, Pono.(1989). Dasar-Dasar Proses Belajar Mengajar. Bandung: Sinar Baru.

Creswell, John W. (1994). Research design. Qualitatve, Quantitative and Mixed Methods Approaches. London. Sage Publication

Gunara. (2010). Pemberdayaan peran sekolah dalam meningkatkan apresiasi seni dimasyarakat.(Ritme) Jurnal seni dan pengajarannya.8,(1) 50-60.

Pamadhi.(2012). Pendidikan Seni. Yogyakarta: UNY Press.

Sugiyono, (2014). Metode Penelitian Manajemen. Bandung: Alfabeta

Suprapti. (2006).Mengoptimalkan Kecerdasan Musikal Anak Usia TK Melalui Musik. Skripsi. PGTK. Fakultas Ilmu Pendidikan. Universitas Negeri Semarang.Tidak diterbitkan. 